\title{
Contribution of Peer Conformity to Student's Academic Procrastination
}

\author{
Triani Arfah ${ }^{1, *}$, Muhammad Tamar ${ }^{2}$, Norhafizah $^{3}$ \\ ${ }^{1}$ Department of Psychology, Faculty of Medicine, Hasanuddin University \\ ${ }^{2}$ Department of Psychology, Faculty of Medicine, Hasanuddin University \\ 3Department of Psychology, Faculty of Medicine, Hasanuddin University \\ *Corresponding author. Email: trianiarfah@unhas.ac.id
}

\begin{abstract}
Procrastination is the tendency to delay tasks. From starting to finishing a job only to do useless activities, eventually leading to regret (Solomon and Rothblum, 1984). There are two consequences of procrastination; these include the emergence of negative emotions, regret, self-blame, and hopelessness. One of the factors that cause individuals to procrastinate is peer conformity, i.e., changes in individual behavior to align themselves more closely with group/friend standards. Changes in behavior that are carried out are not just behaving or acting according to what other people do but are also influenced by how the group acts. This study aims to determine how the contribution of peer conformity to student procrastination. This study uses a quantitative approach. The sample of this study consisted of 348 students at one of the public universities in Makassar City. Academic procrastination was measured by using a scale created by Rindita Ratu C. (2017), which refers to the aspect of procrastination according to Ferrari (1995). Meanwhile, peer conformity is obtained using the scale created by Rindita Ratu C. (2017), which refers to the conformity aspect proposed by Taylor (2009). Hypothesis testing using simple regression analysis using IBM SPSS 18 for windows. The R-square value is 0.311 , which means that the peer conformity variable has an effect of $31.1 \%$, and other variables influence the rest. Peer conformity variable shows a significance value of 0.000 which is smaller than 0.05 , and the t-count value is 9.174 , which is greater than the t-table value of 1.965. It can be concluded that there is a contribution of peer conformity to academic procrastination. $\beta$ value obtained in the peer conformity variable is 0.422 . This means that adding 1 unit of the peer conformity variable will increase the student's academic procrastination by 0.422 .
\end{abstract}

\section{Keywords: Procrastination, Peer Conformity, Students}

\section{INTRODUCTION}

Procrastination is an individual's tendency to intentionally delay tasks which causes a negative impact in the form of feelings of regret and discomfort to the procrastinator [1,2]. Meanwhile, academic procrastination is a delay on formal tasks, especially in the academic field, such as making assignments, final assignments, studying before exams, delaying reading books and references for assignments, and delaying doing administrative tasks and attending academic meetings $[1,3,4]$.

Migrants divide aspects of procrastination into several divisions, which are as follows [5]:

1. Involves an element of procrastination where a procrastinator will tend to procrastinate and delay starting work on a task until it is completed.
2. Produce products, results, and outcomes that are far below the standard. For example, delays in collecting assignments or completing thesis. So, the results obtained are less than optimal.

3. Involves a task that is considered important to do. Although procrastinator realizes the importance of the task and the work to be completed immediately, they don't work on it immediately

4. , producing an unpleasant emotional state. Procrastination behavior causes tasks to be done late, less than optimal, and last minute. This causes negative emotions such as anxiety and worry.

There are negative consequences that individuals get when procrastinating. Internally procrastination causes regret, self-blame, hopelessness, self-criticism, shame, anxiety, fear, lack of concentration, and 
inability to enjoy other activities. Procrastination also causes tension, physical pain, panic, depression, stress, insomnia, feeling incompetent, and feeling constantly chased at higher levels. For other people, procrastinators look fine and may even have achievements. Still, the procrastinators feel tortured, frustrated, and angry with themselves for procrastinating, so the work they believe can be completed is not carried out $[4,6]$.

Students who procrastinate do assignments when they are so close to the deadline that they become less than optimal, grades are decreasing, and they do not participate in training or activities that can increase knowledge. This causes a decrease in academic achievement [4]. Several studies have shown that procrastination is negatively correlated with academic achievement. The higher the level of individual academic procrastination, the lower the academic achievement obtained [5,7].

Although procrastination can harm individuals who do it, the level of procrastination in the academic field is still quite high. [1] found that in 342 American universities, $46 \%$ of students always procrastinate writing assignments, $27.6 \%$ procrastinate studying for exams, $30.1 \%$ delay reading, and consider procrastination as a problem. Ellis \& Knaus [8] found that $95 \%$ of students procrastinate from the beginning to completion of assignments in America, and as many as $70 \%$ of students often procrastinate. Burka and Yuen estimate that procrastination continues to increase by $75 \%$, and as many as $50 \%$ of students admit that they do procrastination consistently and consider it as a problem [4]. Sichan's study on 201 undergraduate, second, and third-level students found that almost $86 \%$ of these students admitted that they procrastinated [9]. Furthermore, 12\% admitted to always and $36 \%$ stated that they procrastinated very often. Meanwhile, research conducted by Kartadinata \& Tjundjing at the Faculty of Psychology, University of Surabaya, found that around $95 \%$ of students admitted to having done academic procrastination [9].

Papalia states that individuals in early adulthood, in this case students, should deal with complex work [11]. This is supported by the development of the Frontal-Frontol Prefrontal Cortex (FPPC) in early adulthood, which functions to plan and convert the desire to delay into action. So that students who have entered early adulthood are no longer procrastinating and can manage time well. However, the high level of procrastination carried out by students indicates that students have not fully developed the function of FPPC, which should have developed in early adulthood.

Several factors influence academic procrastination. Internal factors contributed significantly to procrastination, including selfefficacy, self-control, and time management [10,1215]. However, what is no less important is the external factor that is also the background of procrastination, namely the conformity of peers $[16,17]$. Peer conformity is a change in an individual's behavior to align more closely with group standards. Conformity takes many forms and affects many aspects of an individual's life. Myers defines conformity as not just behaving or acting according to what other people do but also being influenced by how the group acts [18].

Conformity is a form of social influence that comes from friends (peer). Students will try to change their attitudes or behavior to match the norms of their group or social environment. This is done in order to be accepted and not isolated. Myers defines conformity as not just behaving or acting according to what other people do but also being influenced by how the group acts [18]. Conformity is an action or pattern of thinking that is different from the individual's usually done. Therefore, conformity changes behavior, beliefs, or thinking patterns to be in tune with others. Meanwhile, King defines conformity as a change in individual behavior to align more closely with group standards. In the context of work delays, when a group or environment delays an assignment, the student also does it. These factors contribute to high and low procrastination in individuals.

This research was conducted in one of the state universities in the city of Makassar because there are still many levels of academic procrastination carried out by students even though at the beginning of new student admissions there have been prevention efforts in the form of providing character development, one of the materials is managing time and procrastination. However, the results of preliminary research conducted by researchers showed that $48.2 \%$ of students procrastinated and ever been late in submitting assignments (39.6\%). In addition, students also admitted to procrastinating and chose to delay work that was considered unimportant, as much as $48.2 \%$. However, as many as $87.5 \%$ wish to eliminate procrastination behavior by promising themselves to 
reduce the habit of procrastinating completing tasks. This study aims to determine the contribution of peer conformity to student academic procrastination.

\section{METHODS}

This study uses a quantitative approach. There are two types of variables in this study: the independent variable with the symbol (X) and the dependent variable with the symbol (Y). In this case, the independent variable is the conformity of friends $(\mathrm{X})$. While the dependent variable in this study is academic procrastination (Y).

The operational definitions in this study are as follows:

1. Academic procrastination is a tendency to delay work from starting to completing a job or academic task to doing other activities.

2. Peer conformity is a change in an individual's behavior to align more closely with group standards. Changes are made not only in behavior or acting according to what others do but are also influenced by how the group acts.

The sampling technique used is cluster random sampling. Based on academic data from Hasanuddin University, the number of active undergraduate students in the first semester of the 2018/2019 academic year at the university was 24,493 students. The sample size is determined using a table made by Isaac and Michael [19] with an error rate of 0.05; the required number of samples is 348 samples.

The data collection technique used in this study used the Academic Procrastination Scale. Data related to academic procrastination was obtained using the scale created by Rindita Ratu C. which refers to aspects of procrastination according to Ferrari, namely low intentions to start completing tasks, having work standards that are not optimal, there is other work/task that procrastinator felt more important to do, and produces an unpleasant emotional state [20]. Data related to peer conformity was obtained using the scale created by Rindita Ratu C. This refers to the conformity aspects proposed by Taylor, namely imitation, adjustment, trust, agreement, and obedience. This scale consists of 22 statement items consisting of 10 favorable and 12 unfavorable items.

There are two kinds of validity tests conducted in this study, content validity and construct validity.
Content validity is the validity that is estimated through testing the feasibility or relevance of the content of the test on a competent person, namely expert judgment. Furthermore, the readability test was carried out on ten students. In this readability test, several redactions of words in items are changed to be simpler and easier to understand. Next, test the construct validity, namely Exploratory Factor Analysis (EFA) and Confirmatory Factor Analysis (CFA) using SPSS 18.0 for Windows.

Table 1 Academic Procrastination EFA Test

\begin{tabular}{lc}
\hline Aspects & Component \\
\hline Intention to do the task & .787 \\
Working standard & .668 \\
Priority & .858 \\
Negative emotions & .401 \\
\hline
\end{tabular}

The results show that this measuring instrument only measures one component. This can be seen from the table that only produces one component. Next, we take measurements using CFA because it only measures one component at the EFA test. So, the CFA test is carried out as a whole item, not per aspect. The CFA test shows that the estimated value obtained is above $0.5(>0.05)$ and the t-value obtained is also above 1.96 (> 1.96), and the RMSEA is 0.085. Thus, 15 items in this academic procrastination scale are declared valid. Meanwhile, the Cronbach's Alpha value tested using SPSS 18 was 0.783 . then it can be categorized as very good.

Table 2 Peer Conformity EFA Test

\begin{tabular}{lc}
\hline Aspects & Component \\
\hline Imitation & .677 \\
Adjustment & .843 \\
Trust & .897 \\
Deal & .559 \\
Obedience & .698 \\
\hline
\end{tabular}

The results show that this measuring instrument only measures one of the same components so that the CFA test is not based on dimensions but overall. There are several invalid items such as item 2 and item 12 because the loading factor value is -149 (< $0.05)$ and $t$ value is $-1.900(<1.96)$, so it needs to be deleted, then RMSEA $0.100(>0.05)$ so that it is deleted again referring to modification index, then item 16, item 20, and item 17 are deleted because they have modification index. After that, the CFA was retested after the item was dropped. 
After retesting, it shows the RMSEA results is $0.086 \leq 0.08$ with factor loading value $>0.05$ and $t-$ value $>1.96$; it can be said that the construct of this measuring instrument correctly measures the peer conformity variable. There are 11 items on the peer conformity scale that can be used. Based on the reliability statistics table, the Cronbach's Alpha value of the data tested is 0.801 . The Cronbach Alpha value that has been obtained through SPSS 18 can be said to be in a good category.

Data analysis uses simple regression to predict how the independent variable's situation (up and down) as a predictor is manipulated (increases its value). The data that has been obtained in the study will be analyzed using statistical software SPSS ver. 18 for windows. However, the assumption test is carried out, including normality, linearity, multicollinearity, and heteroscedasticity. The results show that the scale meets the requirements to be continued in hypothesis testing.

\section{RESULTS}

\subsection{Student Academic Procrastination Profile}

The following is a graph that shows the percentage of academic procrastination scores obtained from respondents:

\section{Academic Procrastination}

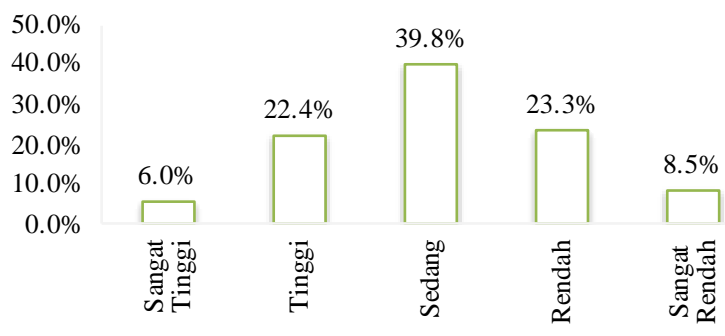

Figure 1. Percentage of Academic Procrastination

Based on the figure, sequentially, students with a very high academic procrastination category are $5.4 \%$ (21 respondents), then the high category of academic procrastination is $22.4 \%$ (79 respondents). Furthermore, the moderate category of academic procrastination was $39.8 \%$ (140 respondents), the low category was $23.3 \%$ ( 82 respondents), and the very low category had a percentage of $8.5 \% \quad(30$ respondents). Therefore, most students have academic procrastination, which is in the moderate category.

\subsection{Peer Conformity Profile of Students}

The following is a graph that shows the percentage of peer conformity scores in university students:

\section{Peer Conformity}

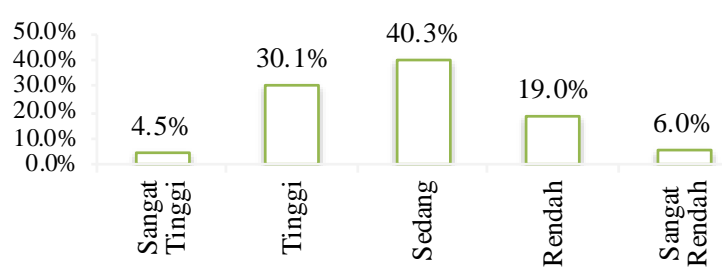

Figure 2. Percentage of Peer Conformity

Based on Figure 2, 30.1\% of respondents get a score of having peer conformity in the high category, and $40 \%$ are in the moderate category, meaning that, in the social sphere, student behavior tends to be aligned with group standards.

Based on the test, it is known that the relationship between variables forms a linear relationship so that the next stage of analysis can be carried out, i.e., hypothesis testing, which multiple linear regression analysis using IBM SPSS 18 for windows. Based on the hypothesis that has been proposed in this study, the results of simple regression analysis can be seen as follows:

Table 5. Simple Regression Friend Conformity

\begin{tabular}{ccccc}
\hline & R & $\begin{array}{c}\text { R } \\
\text { Square }\end{array}$ & $\begin{array}{c}\text { Adjusted } \\
\mathbf{R} \\
\text { Square }\end{array}$ & $\begin{array}{c}\text { Std. } \\
\text { Error of } \\
\text { the } \\
\text { Estimate }\end{array}$ \\
\hline 1 & $0.558^{\mathrm{a}}$ & 0.311 & 0.309 & 4.192 \\
\hline
\end{tabular}

Table 5 above is a regression model for peer conformity. The R-square value is 0.311 it can be seen that the peer conformity variable has an effect of $31.1 \%$ on academic procrastination, and other variables influence the rest.

Peer conformity variable shows a significance value of 0.000 , which means it is smaller than 0.05 . The t-count value is 9.174, which is greater than the t-table value of 1.965 , so it can be concluded that there is a contribution of peer conformity to academic procrastination. The value obtained on peer conformity variable is 0.422 ; this means that each addition of 1 unit of the peer conformity variable will increase the student's academic procrastination by 0.422 


\section{DISCUSSIONS}

This study involved 352 respondents from all faculties at Hasanuddin University. The statistical descriptive analysis test results showed that most of Hasanuddin University students had academic procrastination in the moderate category as many as $39.8 \%$ (140 respondents), followed by students with low academic procrastination with a percentage of $23.3 \%$ (82 respondents). This study also shows that students with high academic procrastination are also quite large, $22.4 \%$ (79 respondents) and very high $5.4 \%$ (21 respondents).

This needs more attention for individuals considering that individuals get negative consequences when procrastinating. Internally procrastination causes regret, self-blame, hopelessness, self-criticism, shame, anxiety, fear, lack of concentration, and inability to enjoy other activities. Procrastination also causes tension, physical pain, panic, depression, stress, insomnia, feeling incompetent, and feeling constantly chased at higher levels. In addition, procrastination also impacts declining academic achievement [4]. Several studies have shown that procrastination is negatively correlated with academic achievement. The higher the level of individual academic procrastination, the lower the academic achievement obtained [8,10,21].

There are still quite some students who do procrastination which is not an expected situation considering Hasanuddin University already has a prevention program by providing BCSS (Basic Character and Study Skill) training which has now changed its name to Balance (Basic Learning Character and Creativity) at the beginning of freshman admissions. One of the materials is about avoiding procrastination through time management techniques. In the guidebook, there is material about procrastination; Gunarya explains that procrastination is a complex problem and can thwart the study's success [22]. Then clearly write down how the stages and how to overcome the procrastination behavior. Although preventive measures have been taken from the start, Hasanuddin University students still do academic procrastination.

In addition, the student period is a time to prepare to enter the world of work, so that the younger generation should be able to manage time well and deal with complex work. It must be prepared and started from students to manage time effectively and efficiently. So that students are able to be more productive and not carry out academic procrastination [11].

This is determined by several factors, which is the conformity of peers as one of the factors contributing to student procrastination. Conformity is an individual's tendency to conform his behavior to group standards. This study found that the level of conformity of Hasanuddin University students was dominant in the moderate category, $40.3 \%$ (142 respondents), then discussed by the high category, $30.1 \%$ (106 respondents). Although conformity peer is not always a negative thing for individuals, Myers reveals that conformity in groups will make individuals behave following what is desired by the group [18]. In that case, it makes individuals do something good that will positively or negatively impact the other individual. It is very important to reduce conformity and make decisions on their own without having to follow others.

Minor hypothesis testing on each variable found a contribution from peer conformity to academic procrastination with a t-count value of $9.174>1.965$ and a significance value of 0.000 . Thus, the higher the level of peer conformity owned by students, the higher the level of academic procrastination they have. This is in line with previous research conducted by Avico and Mujahidin, which found a very significant positive relationship where peer conformity contributed $31.8 \%$ effectively to academic procrastination [16]. Likewise, research conducted by Cinthia and colleagues found that conformity affected student academic procrastination [17].

Ferarri revealed that academic procrastination is influenced by internal and external factors such as the environment and peers when students have high conformity to their friends and groups. Then they will try to be the same as their peers and groups [5]. Taylor adds that the group's desire to be accepted and liked makes individuals do conformity. In that case, it will adjust to the norms adopted by the group [2].

The existence of high peer conformity will certainly affect academic procrastination. When the group or their friends procrastinate or procrastinate on assignments, students with high conformity will follow it and make assignments that should be achieved, which will lead to high academic procrastination. In contrast to students who have low conformity, even though their group or friends delay the assignments and do academic procrastination, 
because that is not in accordance with the values and norms they have, the student is not procrastinated.

\section{CONCLUSION}

Based on the research that the researcher has done, it can be concluded that there is a contribution of peer conformity to student academic procrastination, meaning that the higher the peer conformity that students have, there's potential to increase the procrastination of students. This research was only carried out within the scope of one of the academic communities of a state university in Makassar, so the research results cannot be generalized. In addition, this study does not explore the forms of peer conformity that are often done by students, which hinders them from completing work according to the time and plans that have been made.

\section{REFERENCES}

[1] Solomon LJ, Rothblum ED. Academic procrastination: Frequency and cognitivebehavioral correlates. J Couns Psychol. 1984;

[2] Stell P. The Nature of Procrastination: A MetaAnalytic and Theoretical Review of Quintessential Self-Regulatory Failure. Psychol Bull. 2007;

[3] Ferrari JR, Stevens EB, Jason L a. The Relationship of Self-Control and Abstinence Maintenance: An Exploratory Analysis of SelfRegulation. J Groups Addict Recover. 2010;

[4] Burka.B Jane Y. L. Why you do it, what to do about it now. Da Capo Press. 1983.

[5] Ferrari JR, Johnson JL, McCown WG. Procrastination and Task Avoidance. Procrastination and Task Avoidance. 1995.

[6] Stead, R., Shanahan, M. J., \& Neufeld, R. W. (2010). "I'll Go to Therapy, Eventually": Procrastination, Stress and Mental Health. Personality and Individual Differences, 49(3), 175-180.

[7] Psikologi F, Surabaya U. Apakah Prokrastinasi Menurunkan Prestasi? Sebuah Meta-Analisis Sia Tjundjing. Indones Psychol J. 2006;

[8] Munawaroh M, Alhadi S, Saputra W. Tingkat Prokrastinasi Akademik Siswa Sekolah Menengah Pertama Muhammadiyah 9 Yogyakarta. J Kaji Bimbing dan Konseling. 2017;

[9] He S. A Multivariate Investigation into
Academic Procrastination of University Students. Open J Soc Sci. 2017;

[10] Iven K, Tjundjing S. I Love You Tomorrow: Prokrastinasi Akademik dan Manajemen Waktu. Indones Psychol J. 2008;

[11] Papalia DE. Human Development (Psikologi Perkembangan). Cetakan ke-1. 2015;

[12] Julianda BN. Prokrastinasi dan Self Efficacy pada Mahasiswa Fakultas Psikologi Universitas Surabaya. Calyptra J Ilm Mhs Univ Surabaya. 2012;

[13] Wäschle K, Allgaier A, Lachner A, Fink S, Nückles M. Procrastination and self-efficacy: Tracing vicious and virtuous circles in selfregulated learning. Learn Instr. 2014;

[14] Ursia NR, Siaputra IB, Sutanto N. Prokrastinasi Akademik Dan Self-Control Pada Mahasiswa Skripsi Fakultas Psikologi Universitas Surabaya-Academic Procrastination and SelfControl in Thesis Writing Students of Faculty of Psychology, Universitas Surabaya. Makara seri Sos Hum. 2013;

[15] Aini AN, Mahardayani IH. Hubungan antara kontrol diri dengan prokrastinasi dalam menyelesaikan skripsi pada mahasiswa universitas muria kudus. J Psikol Pitutur. 2017;

[16] Avico R, Mujidin M. Hubungan Antara Konformitas Dengan Prokrastinasi Akademik Pada Mahasiswa Bengkulu Yang Bersekolah Di Yogyakarta. Empathy. 2014;

[17] Cinthia R, Kustanti E. Hubungan Antara Konformitas Dengan Prokrastinasi Akademik Pada Mahasiswa. Empati. 2017;

[18] Myers DG. David G. Myers - Social Psychology, 10th Edition -McGraw-Hill (2009).pdf. 2009;

[19] Sugiyono. Statistik untuk Penelitian. Bandung: Alfabeta. 2014;

[20] Ferrari, J. R., Johnson, J. L., \& McCown, W. G. Procrastination Research. In Procrastination and Task Avoidance (pp. 21-46). Springer, Boston, MA. 1995;

[21] Kljajic K, Gaudreau P. Does it matter if students procrastinate more in some courses than in others? A multilevel perspective on procrastination and academic achievement. Learn Instr. 2018;

[22] Gunarya, A. (2011). Teknik Menangani Prokrastinasi. Modul SS-06. Basic Study Skills Universitas Hasanuddin. Makassar. 